\title{
"It'll be our own little Wales out there": re-situating Bardsey Island for post-devolution Wales in Fflur Dafydd's Twenty Thousand Saints
}

\author{
Kieron Smith \\ Cardiff University, Wales, UK \\ Smithk30@cardiff.ac.uk \\ Jon Anderson \\ Cardiff University, Wales, UK \\ andersonj@cardiff.ac.uk \\ Kirsti Bohata \\ Swansea University, Wales, UK \\ k.bohata@cardiff.ac.uk
}

and

\author{
Jeffrey Morgan \\ Cardiff University, Wales, UK \\ Morganj5!@cardiff.ac.uk
}

\begin{abstract}
This article examines the ways in which Fflur Dafydd's 2008 novel Twenty Thousand Saints negotiates notions of the island space in a post-devolution Welsh context. It argues that the novel is a rich site in the analysis of the literary dimension of what Baldacchino describes as the "island-mainland [...] dialectic" (Baldacchino, 2006, p. 10). Set on Bardsey, a real small island off the coast of north Wales, the novel employs a multiple-character narrative to explore and critique the various ways in which Bardsey has been constructed in the Welsh cultural imagination. In particular, the novel explores the idea of the island as a queer space. It does so in a way that posits Bardsey in dialectical relation to an ongoing, politically dynamic Welsh mainland. The article suggests that the novel can be read as a mainland appropriation of the island in the post-devolution era. Yet this is simultaneously an enabling imaginative act that confirms the power of literature to create new imaginative geographies.
\end{abstract}

Keywords: Bardsey Island, Fflur Dafydd, island studies, literary geography, novel, queer space, Twenty Thousand Saints, Wales

https://doi.org/10.24043/isj.35

(C) 2017 — Institute of Island Studies, University of Prince Edward Island, Canada.

\section{Introduction}

Fflur Dafydd's 2008 Twenty Thousand Saints is a novel set on the real island of Bardsey (Welsh: Ynys Enlli) situated some two miles off the coast of the Llŷn Peninsula in north Wales. In fact, not only does the novel situate itself in a real geographical space, but it also positions itself in relation to real institutions and real events in recent Welsh history. Towards the end of the book, Viv, a character who has been living on Bardsey for nearly thirty years, takes a boat to the mainland 
before heading south to Cardiff to visit the Senedd, the building that houses the National Assembly for Wales. It is Viv's first visit to the Senedd since its opening on the waterfront of Cardiff Bay in 2006; indeed, it is her first visit to the mainland since moving to Bardsey in defiance of the failed referendum on Welsh devolution in 1979. After three decades of self-imposed exile, the scene depicts Viv experiencing a moment of euphoric realization:

How peculiar, she thought, that what she was stood on now was also a kind of island, a piece of land completely segmented from the rest of the city. The water surrounded them, holding these huge buildings afloat, it seemed, with nothing to be seen in the distance but the dotting of tiny lights, which were minuscule in comparison to the huge streaming light which now poured through this building and through Viv, throwing their shadow onto the water as one. And they truly were on an island now, she thought, all of them: the building behind her confirmed it. All the time she had been away, Wales had been prising itself away from the mainland at its border. (Dafydd, 2008, p. 243)

Once a fervent political activist, Viv here approaches the changed city almost as the archetypical curious, out-of-touch tourist: "how peculiar, she thought..." (2008, p. 243). However, her perception soon shifts as the profound political significance of the Senedd building dawns on her. Her attitude towards the Wales she once viewed as abjectly defeated transforms into one of participation in a newly confident, self-determining nation. Her small nation, annexed to England since the Acts of Union of 1536-43, now has its own political assembly: a realization of such magnitude that it enables Viv not even to name the ruling state beyond the border, but to visualize Wales as, itself, "truly [...] an island now" (2008, p. 243); that is, a Wales separate and self-determined, radically enisled.

Wales is not, of course, an island. It is a small nation within the United Kingdom of Great Britain and Northern Ireland, sharing a border with England and consisting of two large peninsulas protruding from the western edge of the largest of the islands in the archipelago off mainland Europe. The long- windedness of such a description and its nomenclature is, of course, symptomatic of the overdetermined and contested nature of national identities in this "Atlantic archipelago" (Norquay \& Smyth, 2002). Relatedly, the political positionality of Wales within the UK has shifted significantly over the past two decades. A referendum in 1997 resulted in the formation of the devolved National Assembly for Wales in 1999, and, while it initially possessed only limited powers, in a nation politically annexed to England for close to six centuries, the implications of this measure of political independence in the social, political, and cultural imagination were profound. Since then, further executive powers have been afforded, following the establishment of the Welsh Assembly Government (now simply Welsh Government) in 2007, as well as the referendum on further devolved powers in 2011 (see Jones \& Scully, 2012). Published in 2008, but set, it appears, soon after the opening of the Senedd building in 2006, Twenty Thousand Saints is a novel acutely attuned to these changes in Wales's political geography. It is also, as the above passage demonstrates, a novel that is explicitly concerned with Wales's imagined geography, or, more specifically, with Wales as a "place" that is situated, as are all places, "at the intersection between context and culture" (Anderson, 2015, p. 6). These are features of the novel that are illuminated in light of recent developments in the emerging field of Literary Geography, which develops the spatial turn in literary and cultural studies. This is a field that is concerned not only with the representation of so-called 'real' spaces in literature, but with the "entanglements" of literature and space (Anderson, 2014, p. 12), or, in Alexander's terms, "the nature of the relationship between material and metaphorical spaces" (Alexander, 2015, p. 5). A key thread in this "entanglement" of the literary, the spatial, and the social in Twenty Thousand Saints is the novel's construction of Bardsey Island. In particular, the novel is concerned with a depiction of the relationship between Bardsey Island and mainland Wales, or with what Godfrey Baldacchino (2006, p. 5) has called the "island-mainland dialectic," a key feature of the various, sometimes "paradoxical" ways in which islands are imagined (Baldacchino, 2006, p. 10). Taking 
its cue from these ideas, this article will explore the features of this novel's construction of Bardsey, and, correlatively, its relationship with mainland Wales.

\section{Islands in Welsh culture}

Islands are a key trope in certain areas of Welsh literature and culture, so much so that it might be possible to describe Wales as an 'islophiliac' nation, one enthralled by the figure of the island (Hay, 2006 , p. 22). In a geographical sense, this is perhaps unsurprising, given the sheer number of islands peppering the coastline of this small nation, from tiny, uninhabited islands such as Ynys y Bîg, to the administrated county of Ynys Môn (Anglesey). There are political explanations for this islophilia, too. Wales is a nation whose historical annexation to its dominant neighbour has resulted in a conflicted, tangled sense of its own cultural and political identity. A number of commentators have employed the idea of a 'postcolonial' Wales to make sense of these tensions (see Bohata, 2004, and Aaron and Williams, 2005). This is arguably a model that can foreground cultural and political relations with the 'coloniser' rather than separateness. Meanwhile, the connotations of islands render them valuable sites of potential in those areas of Welsh consciousness that endorse the idea of an independent Wales. After all, unlike the messily informal land border between Wales and England, the clear physical borders of islands are hard to dispute. As Pete Hay suggests, the attractiveness of the idea of 'islandness' is connected to the "sharpness of that wave-lined boundary" (Hay, 2006, p. 22). "Islophiles," says Hay, "tend to extol this sense of insularity; to see it as [...] a state of existence to be cherished" (2006, p. 22). One of the earliest Welsh myths, told in Second Branch of The Mabinogion, includes the enchanted island of Gwales where the head of Bendigeidfran and his followers abide for eighty years until one of them opens a door that looks towards the mainland (Cornwall) and their suspended defeat in battle is suddenly recalled and they are full of grief (Davies, 2007, pp. 33-34). Bardsey has an important literary history of its own, including the poets R. S. Thomas and Christine Evans and, perhaps most famously, the Welsh islophile artist and writer Brenda Chamberlain, who spent fourteen years living on the island before later moving to the Greek island of Hydra. Chamberlain's idiosyncratic memoir Tide-race (1962) is a profound meditation on the imaginative life of Bardsey and, as suggested by the title's reference to the quick, treacherous shifts of tidal currents around the island, on the stirrings of inner, emotional tides. Tide-race is a strong presence in Dafydd's novel; indeed, Twenty Thousand Saints borrows one of its epigraphs from the former. Where Brenda Chamberlain explored the idea of the island as a means of channeling what Damian Walford Davies (2012, p. 90) sees as an "ambiguous relation to what she saw as the constraining enislement of national identity," recent explorations of islands in Welsh culture have adopted the island as a figure for a positively imagined, independent sense of Welsh national identity. This has been particularly prominent in the years since the establishment of the National Assembly for Wales. The exemplar on this score is the work of the Welsh visual artist Iwan Bala, many of whose paintings since devolution have explored variations of the conceit of a Wales cartographically liberated from England. Bala's efforts to visualize Wales in these terms can be viewed as a part of a wider cultural shift in post-devolution Wales. The imagined nation-as-island is not a homogenous space, however. As Thomas and Aaron (2003, p. 305) have observed, "with a greater degree of independence, and the strengthening of the sense of identity that it gives, has come a greater capacity to recognize and accept the diverse elements within Welsh culture." Here the authors refer to the shift in certain areas of Welsh culture from a concern with Wales's complex relationship with English and British culture, and, indeed, with the very question of Wales's own separate existence, to a more self-assertive, self-determining concern with the nation's own "internal differences" (Thomas, 1992) and a new civic nationalism.

As is implied in Viv's euphoric vision of a Wales that has "prised itself away from the mainland" (2008, p. 243), Twenty Thousand Saints should be read as a key example of this trend. However, Dafydd's novel not only explores the figure of a Wales imaginatively enisled. The 
novel relatedly evokes Bardsey Island as a space that exists in relation to Wales, one in which characters explore, challenge, and redefine the various facets of their Welsh "mainland" identities. This engagement with islandness confirms Marc Shell's observations on the figure of the island as a "laboratory" in literary culture (2015, p. 93). There, Shell notes that "thinking about 'small' or 'deserted' $[. .$.$] islands can make for representative case studies of understanding the 'large'$ world" (2015, pp. 94-95). Bardsey, in reality and in Dafydd's novel, is hardly deserted, and the dynamics of the island population as it rubs shoulders with the summer visitors is a central part of the novel. But Dafydd was conscious of the way the island laboratory could enable her to explore questions about the "large" world that is, in this novel, Wales. There she discussed the extent to which she was inspired by a stay on the island, during which she met people from all walks of life: "it's very energising for a writer to encounter all those different people and then to try and put them into a novel and then to try make them somehow emblematic of the society of Wales" (Dafydd, 2016, n.p.). This article suggests that the novel's construction of Bardsey as a "laboratory" or a space "emblematic" of Wales contributes to its sense of the Welsh nation as a figurative islanded mainland, rather than a peripheral region of a larger nation state.

A key feature of the effectiveness of Twenty Thousand Saints lies in the novel's critical awareness of the ways in which Bardsey has been constructed in the Welsh cultural consciousness. Bardsey is most famous as a site of Christian pilgrimage, having been an important site for the Celtic Christian Church from the sixth century, and later the location of an Augustinian Abbey that was in use until the Dissolution of the Monasteries. It has, as a result, long been known as 'the island of 20,000 saints'. As the poet Hywel ap Dafydd ap Ieuan ap Rhys wrote in the fifteenth century: "This land has been sown and cultivated/With the bones of Saints/Who have been put in this earth" (quoted in translation in Daniel, 1955, pp. 12-13). It was said at the time that three visits to Bardsey were equal to one to Rome (Bardsey Island Trust, n.d., n.p.), something that Viv points out early in the novel $(2008$, p. 24). In later years, however, the island became a haven for pirates, and gained for itself a certain notoriety: by the seventeenth century, Bardsey was associated in the popular mind with the adventures of "the wildest elements of a society which had lost hold of its own essential order" (Daniel, 1955, p. 26). Order was restored in the nineteenth century when the island prospered as a farming, fishing, and lime-quarrying community, and it now has a small resident population, with a working farm and resident wardens that oversee the island as a wildlife sanctuary and tranquil tourist spot (Evans \& Marloh, 2008). This long and shifting social history has meant Bardsey is an island that figures uneasily in Welsh mainland consciousness. This is further compounded by its geographical detachment; separated from the tip of the Llŷn Peninsula in north Wales by two miles of treacherous, often impassable waters, the island, viewed from the mainland, "wears an austere aspect" (Chamberlain, 1962, p. 13). Its physical topography accentuates this, with Mynydd Enlli, the large, craggy mountain rising from the northeast of the island, obscuring much of the pastureland from view. It is for this reason that Peter Hope Jones (Hope Jones \& Thomas, 1998, p. 11) describes Bardsey as "janus-like", and this is perhaps part of what has made Bardsey such an enticing attraction for a stream of artists and writers over the years. Its geographical aloofness, combined with its tantalizing social history, renders Bardsey an alluring creative space. A vast range of Welsh creative figures have been enamoured with the island over the centuries: Moses Griffiths, R. S. Thomas, Christine Evans, to name only a few besides those already named. In his book on Bardsey, Hope Jones (1998, pp. 11-15) usefully groups the representations of the island under a number of categories: "physical," "historical," "wildlife," "cultural," "metaphysical," and concludes that, despite its myriad representations, the island can ultimately be viewed in its essence as a "fascinating whole" (1998, p. 15). Dafydd's novel self-reflexively engages with and critiques these popular images of Bardsey, showing them to be questionable constructions of mainland Welsh consciousness. In doing so, the novel demonstrates an awareness of Bardsey as, to borrow Marc Shell's phrase, "both a world apart and a part of the world" (2015, p. 94). In other words, the novel constructs Bardsey in a way that does not essentialize it in quasi-mystical terms as a "fascinating whole," but rather attends 
to the island's construction as "a part of" an ongoing, dialectical relationship with a politically dynamic Welsh mainland.

\section{Ironizing constructions of Bardsey in Twenty Thousand Saints}

What is immediately clear about Twenty Thousand Saints is the novel's anchoring of itself to the spatial reality of Bardsey. The island's geographical terrain, landmarks, toponymy, are all faithfully rendered. In Reuschel and Hurni's terms, the novel does not "invent" or "transform" locations, but directly "imports" them into its narrative space (Reuschel \& Hurni, 2011, p. 296). This suggests the novel is intended to be read as a work of social realism; that is, a work of fiction, but one nevertheless positioned within and to be read against Welsh spatial reality. Complementing this construction of Welsh spatial reality is the novel's attention to Welsh political reality. Indeed, the chronology of the drama that unfolds in this space is pinned directly to key dates in Welsh political history. The novel is set in 2007, the year in which the Senedd building in Cardiff Bay was opened and in which the Government of Wales Act 2006 was implemented, a move that afforded Wales further legislative powers through the creation of a Welsh Government. However, the narrative is tied to a series of events set in motion by the referendum on devolution of 1979, in which an overwhelming "no" vote was delivered by the Welsh electorate: $79.7 \%$ voted against devolution (Jones \& Scully, 2012, p. 62). Following this crushing defeat, Viv and Delyth, two passionate supporters of Welsh independence, resolve to retreat from a nation that they view as an insufficiently 'Welsh'. They remove themselves and their respective sons, Iestyn and Deian, to a Welsh-speaking world on Bardsey. "It'll be our own little Wales out there" (2008, p. 131), Viv tells Delyth in a succinct encapsulation of Polack's observation that islands are frequently evoked as "perfect microcosm[s] of... national concerns" (Polack, 1998, p. 217). After the successful 1997 vote, Delyth begins to consider a move back to the mainland, but is frustrated by Viv's stubborn reluctance to leave. As Iestyn tells his mother: "Delyth knew you wouldn't leave... She didn't want to go without you. But she knew that if she stayed, she'd be forgotten completely, swallowed up by this place. She had to do something drastic" (2008, p. 214). This "something drastic" is suicide; Delyth drowns herself in a cove behind Mynydd Enlli. The disappearance of her body sparks an investigation that results in the conviction of Iestyn for her murder, for which he spends ten years in prison. The thrust of the novel's drama centres on Iestyn's return to the island and the eventual revelation of the truth of Delyth's death.

While it is this story that forms the spine of the novel, a multitude of other characters populate the narrative space, and the novel attends to these characters' perspectives by counterpointing chapters of free indirect speech focalizations. The thematic focus of each character's personal story is in some way related to his or her relationship with the mainland; all of the main characters to some extent use Bardsey to escape an existence on the mainland that has become personally unfulfilling. The questions that each character asks of the island as a result of their mainland ennui-spiritual, romantic, professional — can be read as figurations of constructions of Bardsey in the Welsh consciousness, and Twenty Thousand Saints skillfully plots these narrative arcs in a way that dramatizes and ironizes such constructions. Notably, each character's construction of Bardsey involves an act of deception. Viv's desire for isolation after Delyth's disappearance results in her misusing the notion of Bardsey as, in Hope Jones's terms, a "metaphysical" site of spiritual pilgrimage. Viv becomes a nun and recasts Delyth as a saint. However, as part of a wider religious network, Viv resents having to invite nuns from other islands to a pilgrimage on Bardsey, and this leads her to:

downplay Bardsey from the very beginning, keeping tight-lipped on the subject of the twenty thousand saints, and of the hermitage next to her cottage. She certainly wasn't going to volunteer the information that three pilgrimages to Bardsey equaled one to Rome. They can go to Rome on a special offer, she'd thought, it's not that expensive. (2008, p. 24) 
The novel uses comedy to take a light touch on the moral implications of Viv's questionable relationship with her faith, yet the above passage nevertheless makes clear the ways in which the mythology of Bardsey has, in the modern age, become emptily commodified; transactional rather than spiritual. Similarly, Deian exploits the 'historical' image of Bardsey as a goldmine of archeological treasure in order to both (unsuccessfully) entice his partner to join him for a retreat on the island, and to trick mainland visitors into helping him conduct an uninteresting land survey. He plants bogus finds in the soil to keep his assistants interested. Again, in a focalized scene alluding to the ways the essential emptiness of the island has been filled with dubious mythologies, Deian thinks, "As long as he gave them something, it was easy enough to keep the nothingness at bay" (2008, p. 31). Mererid is a poet commissioned as a writer-in-residence on the island, but it becomes clear that her taking up of the position involves a contrived exploitation of the island as a 'cultural' space. In fact, Mererid does not seek to find inspiration but to escape an impending marriage to a man whom she "does not quite love" (2008, p. 17, italics in original.), and it is, appropriately, a geographical metaphor that is employed to evoke Mererid's inner turmoil: "She's just not sure where she stands on this. She is nowhere" (2008, p. 17). Mererid assumes that situating herself on the island geographically will somehow allow her to find firm footing emotionally. Indeed, the novel frequently returns to the use of island imagery to ironize problematic emotional landscapes. Leri is a television documentary filmmaker who has come to produce a film about Iestyn's return to the island. She represents a brand of single-minded mainland careerism, and foolishly attempts to control events on the island for her own needs. She misuses the popular images of Bardsey as a physical site of natural beauty by using these to deceive her co-producer, Greta, into helping her produce a documentary that exploits Viv and Iestyn's story for her own ends. Leri's grandly aspirational mentality is ironized through a vision of island isolation: "By showing people this island, she would break free from the mass herself" (2008, p. 124). The novel brilliantly evokes Leri's escalating delusions as her vision becomes gleefully elaborate: "she would float off, people would start coming to her, in flocks of white boats. Yachts, even" (2008, pp. 124-125). Though viewed through Leri's eyes, this comically delusional image succinctly captures the foolishness of each of the characters' attempts to control their experiences of Bardsey.

\section{Resituating Bardsey}

The novel's ironizing of the multiple ways Bardsey has been constructed in mainland Welsh consciousness can be read as a postmodern intervention in constructions of Bardsey, deconstructing as it does the idea of Bardsey as a "fascinating whole." Yet interestingly, the narrative logic it employs in doing so serves to resituate the island space as one that possesses a peculiar enigmatic, instructive power over its characters. Bill Holm has written of the sense in which islands are, by virtue of their enclosedness, often constructed as instructive spaces. Enabled by their ability to "reduce the world for a while." islands can be spaces in which we are "able to think about what is true at the bottom of our own character" (2000, pp. 11-12). In a related vein, Baldacchino has observed that in fictional islands, characters often return "refreshed, redeemed" or "somehow transformed, by the experience" (2006, p. 5). This sense of moral instruction is certainly true of the construction of Bardsey in Twenty Thousand Saints, though this is not only as a consequence of its diminutive size. This is partly signaled by a narrative voice that hints at the island's omnipotence:

Bardsey wasn't going to make it that easy. There wouldn't be a boat for days, now, or so they said. Days. The tide-race was restless, and they'd had no choice but to cancel [the boats], in fear of visitors being swallowed up by the Bardsey Sound on their way home. (2008, p. 116) 
This passage is characteristic of the novel's mode, in which the flippancy of the narrative voice flirts with the implied presence of a deeper, quasi-mystical power possessed by the island and the waters that encircle it. From the comically conversational tone of the first sentence's suggestion that the island has a will of its own, the narrative voice shifts to something more philosophically suggestive: "The tide-race was restless" (2008, p. 116). The reference to Brenda Chamberlain's book chimes loudly here, a book which itself explores the features of the churning, tumultuous waters that swirl around Bardsey as somehow beyond or beneath rational comprehension.

This sense of deeper, uncontainable forces troubling its characters' powers of comprehension is further signaled in one of the novel's central images: the 'attraction', a natural phenomenon in which a flock of various species of bird becomes mesmerized by the circling light of the island's lighthouse, some of which, unable to see clearly, crash fatally into the building. The image is an eloquent symbol of the folly of this group of characters each attempting to ask too much of an island space. Indeed, the ways in which respective characters respond to the attraction signals the sagacity (or otherwise) of their relationship with the island itself. Leri, for instance, is arrogantly dismissive of the attraction. It proves to be something totally beyond her world view, shaped as that is by a desire to control the island space for her individualistic ambitions: "whatever had happened," she thinks, "it took the edge off her own little drama" (2008, p. 65). However, another of the island's inhabitants, Elin, a warden who has spent some time on Bardsey, knows better than to attempt to understand it on her own terms. Elin is a physical, self-assured presence in a novel of flighty, neurotic characters, and, although conscious of the curious power of the island as a place where, in her words, "[y] our mind plays tricks," where "you can easily forget that you're a complete, real person" (2008, p. 11), she does not allow herself to be troubled by it. Rather than attempt to perceive the attraction within a preconceived framework of understanding-or, like Leri, use it to her own ends-Elin simply revels in the sheer physicality of the event: "some of them just fly straight into it and die-bam!' She slammed her fist on the table a little too hard, leaving a cereal bowl trembling" (2008, p. 67). Thus the island for Elin is not something to be constructed or shaped by preconceptions, but experienced and respected on its own terms. Indeed, Elin's later cryptic remark in response to the attraction hints at the novel's wider construction of Bardsey: where Mererid is troubled by the attraction, viewing it as something "that's gone horribly wrong, something unnatural," Elin refuses to be disturbed: "unnatural things happen for a reason," she says wisely (2008, pp. 67-68). Attempting to comprehend the island is foolish, Elin implies; this is a space only to be experienced, to learn from.

\section{Queer Utopia?}

A key feature of the way Twenty Thousand Saints resituates Bardsey is its exploration of the island as a locus of queer possibility which offers an alternative to the norms of the mainland. In Dafydd's novel, Bardsey is portrayed as predominantly Welsh-speaking. Indeed the island itself communicates in that language: "the island that had spoken to [Deian] when he was a child, in Welsh" (p. 58). In reality, the transient population of ecologists and tourists speak little Welsh, as Dafydd notes. Yet she has compared the geographical boundedness of the island with the Welsh-language community: "The one thing they have in common is the island; the fact that they're all there. In a way, you know, they made me think about the Welsh-language community and what we all have in common is the language. We might be very, very different and have different perspectives but that unifies us" (2016, n.p.). And the desire to raise their children through Welsh is what inspires the two women to set up home off the mainland. The utopian alternative Wales Dafydd's creates on Bardsey is decidedly feminist: a matriarchy dominated by Mwynwen, as well as Viv and Delyth's queer family. The island also encourages sexual experimentation, playing with desire, testing the authenticity of relationships (straight and gay), while also circling around the question of parenthood. In one remarkable scene the adolescent sexual curiosity of the two friends, Iestyn and Deian, ends in the latter ejaculating miserably on 
the mountainside. He watches his semen drying in the sun "wondering if it was possible for him to reproduce some strange hybrid grass child with a luxurious green coat and his own brown eyes" (2008, p. 112), an image that haunts him as an adult when he discovers that he is infertile and he realizes his semen was "destined to stay there, on the island, to go no further" (2008, p. 112).

Same-sex desire is a central presence in the novel, though perhaps not entirely unproblematically. Kirsti Bohata has noted that the novel follows a thread of writing on same-sex desire in Wales that extends over several hundred years (Bohata, 2016, p. 94). Such writing often draws on constructions of Wales's cultural and political marginality in ways that aligns them with a queer sexuality that is "linked to wildness, sensuality, a primitive landscape, passionate excesses and an ancient paganism, as well as oppositionality and 'difference"' (Bohata, 2016, p. 108). The island is a space that facilitates queer desires in its remoteness, particularly between women. In this one could trace a literary heritage that locates stories of same-sex relationships in all-female spaces of the convent or girls school (Bohata, 2016, p. 95). The novel opens with a languorous passage of the novel, observed by the lesbian filmmaker, Leri:

Men were scarce that summer. The women of Bardsey Island had begun giving each other languorous looks; had begun talking to each other in quivering, feverish tones. Most of them didn't even realize they were doing it. (Bohata, 2008, p. 7)

As the novel unfolds, Leri and Greta consummate their long-standing attraction on arrival on the island. Their new closeness is articulated in the language of island geography. The house in which Leri and Greta stay on Bardsey is viewed as a kind of island: it is named (after the real house on Bardsey) 'Carreg Bach', which translates as 'the small rock'. Leri, on some level, understands it to be "somehow, the perfect cottage", seemingly because it resembles an island: "perched just on the lower limbs of the Bardsey mountain, a pop-up house, springing out of the grass." It is a cottage "right at the heart of the island, yet somehow resolutely apart." Here, in this islanded cottage, she looks for some physical sign from Greta to "confirm that it was where she intended to be, and that she hadn't just been washed ashore there on the tide of her dreams" (2008, p. 35). Leri begins to find her internal compass shifted by her feelings for Greta:

Leri wondered if either one could bring themselves to discuss what was happening between them. Balance wasn't the right word [...]. If there had ever been any, it had long sloped into some asymmetrical, slanting mess. Leri's entire world had tilted towards Greta [...]. [I]t was the kind of thing you didn't mention, until the tilt solidified, until the whole world seemed a little off centre. $(2008$, p. 8)

Later their relationship will fail because of Leri's deceitfulness, but for a time their "off centre" attraction provides a model for Viv to understand what she felt for Delyth:

Viv saw something between them as Greta took the clipboard. The slight linger of Leri's palm against Greta's back, Greta exuding a bright smile. Viv wanted to ask them if it was worth it, what they'd done, the one thing she and Delyth had never dared to do. (2008, p. 182)

Viv's unrequited desire for Deltyh underpinned her wish to stay on the island when Delyth was ready to leave; thus her sexuality and nationalism are entwined. Her wistful memories of their first and last kiss and the sexual jealousy between Viv and her son as they compete for Delyth dominate her half-stifled memories of the past. Perhaps her anxieties were well founded. While Bohata has argued that for most of the novel Bardsey is constructed as "a vibrant and seductive space of sexual fluidity and experimentation" (Bohata, 2016, p. 110), like Shakespeare's The Tempest, the island is a space in which experiments can occur, only to return to 'normal' on the 
mainland. Although the novel makes clear that mainland Wales-particularly Welsh-speaking Cardiff-is home to a lively gay scene, the same-sex relationships initiated, and desires explored, on the island do not survive the return to the mainland at the end of the book; the only relationship to flourish is a heterosexual relationship between Mererid and Deian, though this is complicated by Deian's infertility (Bohata, 2016, p. 112).

The construction of the island as a space in which the limitations and contradictions of personal and political realities on the mainland are tested and resolved is further exemplified in the revelation of the truth of Delyth's disappearance, and the resulting resolution of Deian and Viv's narratives. Indeed, the unresolved disappearance of Delyth in 1997, if read against the positive outcome of the referendum on devolution that year, can be viewed as a deeply politically symbolic event. It had resulted in Deian and Viv both undergoing a severe crisis of identity, each retreating from mainland Wales in different directions, with Deian moving to England and abandoning his Welshness - signified through his loss of the Welsh language — and Viv abandoning any sense of mainland political progress, choosing to retreat into self-imposed isolation as a nun. However, Iestyn's return (timed just after the Government of Wales Act 2006 and the establishment of the Senedd) results in the revelation that Delyth's suicide was a deliberate act of martyrdom, designed to inspire her island family into a reassessment of their relationship with mainland Wales. This having been revealed, Deian gradually begins to relearn Welsh, an act that is viewed in quasi-mystical terms as taking place in tandem with his physical presence on the island: "He felt something, right then, on the edge of the mountain, the sea beneath him laughing, the language rolling around in his mouth once again; a curious moment of balance" (2008, p. 193). Deian's personal realization is figured spatially; here, it is as if Deian is in conversation with the very island on which he stands. As a result of discovering the truth of his mother's disappearance, Deian resolves to forge a new relationship with his nation, making him "more determined than ever to use the language, to live in Wales, to use that anger, that tension in him to wonderful effect" (2008, p. 222). Meanwhile, Viv, having learned the truth of Delyth's disappearance, is finally convinced that she needs to see the Senedd building for herself: the result is an epiphanic experience in which she comes to terms with the ongoing, dynamic nature of the Welsh polity. In that scene, Viv becomes one with a Wales figured as an island: "the huge streaming light... poured through this building and through Viv, throwing their shadow onto the water as one." Here the personal is reconciled with the political, as Viv is finally able to view Wales in the way she viewed Bardsey: as a renewed, politically active mainland nation.

\section{Coda}

In a recent interview in which Dafydd talked about the iconic importance of Bardsey to Wales, she noted that, prior to writing Twenty Thousand Saints, she had:

felt that there was a gap in English-language literature specifically about Bardsey. There'd been nothing specifically since Bardsey had been portrayed in Brenda Chamberlain's Tide-Race, so I thought, well, this is another opportunity to bring the island to the attention of a wider readership. (Dafydd, 2016, n.p.)

Such a remark appears to confirm this paper's central argument, namely that Twenty Thousand Saints is a novel that intervenes in the construction of Bardsey's islandness in post-devolution Welsh consciousness. Anchoring its narrative in Welsh geographical and political reality, the novel ironizes traditional images of Bardsey while simultaneously invoking Bardsey as an instructive, queer, laboratory space. It does so in order to invigorate notions of post-devolution mainland Welshness. Specifically, the novel imaginatively resituates the island in dialectic relation to mainland Wales in a way that posits the latter as a politically dynamic space. Through the evocation of this dialectic, Wales is no longer culturally or politically peripheral; it is the centre to which 
Bardsey is a periphery. In this sense, the novel can perhaps be interpreted as constituting a problematic "appropriation" (Hay, 2006, p. 30) of Bardsey's islandness. Certainly, the islanders' hostile responses to Dafydd's Welsh-language novel, Atyniad (2006), on which Dafydd based her much revised English-language text, were based on a sense of Dafydd's misrepresentation of the island. Indeed, comparing Twenty Thousand Saints with another recent literary representation of Bardsey highlights this. Christine Evans is an Anglophone Welsh poet who has lived seasonally on Bardsey for some forty years (Jarvis, 2008, p. 107), and whose poetry, particularly in her 1995 collection, Island of Dark Horses, frequently returns to the place and space of Bardsey. For Jarvis, the strength of Evans's work lies in the ways it constructs the island not in homogenizing, essentializing terms, but as a "crucially shifting field," "a place of paradoxical doubleness (both homely and mysteriously remote)" (Jarvis, 2008, p. 117). While certainly demonstrating an awareness of the dialectical construction of Bardsey, compared with Evans's work, Dafydd's novel appears to position the island as ultimately peripheral to the Welsh mainland. Dafydd herself self-consciously exploits the tensions of the dynamic between island and mainland, insiders and outsiders, the possibilities of plot and the metaphors afforded by the island geography. Indeed, Dafydd's novel demonstrates the extent to which literature about place enables us, in Damian Walford Davies's terms, to "go beyond mere "formal geometries" of the ways we map physical geography in order to cartographically imagine an "alternative social space" in the cultural and political consciousness (Walford Davies, 2012, p. 12). Twenty Thousand Saints imaginatively resituates Bardsey in order to generate a conception of Wales in the post-devolution era as dynamic, self-determined, figuratively enisled.

\section{Acknowledgements}

The research for this article was enabled by the AHRC-funded project A New Literary Geography: Establishing a Digital Literary Atlas for Wales and its Borderlands, based at the School of Geography and Planning, Cardiff University, and CREW (the Centre for Research into the English Literature and Language of Wales), Swansea University. The outcome of this project will be an interactive website which will offer a range of digital 'deep maps' of Anglophone novels set in Wales. For more information, see www.literaryatlas.wales.

\section{References}

Aaron, J. \& Williams, C. (2005). Postcolonial Wales. Cardiff: University of Wales Press.

Alexander, N. (2015). On Literary Geography. Literary Geographies, 1(1), 3-6.

Anderson, J. (2014). Page and place: ongoing compositions of plot. Amsterdam: Rodopi.

Anderson, J. (2015). Understanding cultural geography: places and traces $\left(2^{\text {nd }} \mathrm{ed}.\right)$. London: Routledge. Baldacchino, G. (2006). Islands, island studies, Island Studies Journal. Island Studies Journal, 1(1), $3-18$.

Bardsey Island Trust (n.d.). History. http://www.bardsey.org/history.

Bohata, K. (2016). "A queer kind of fancy": women, same-sex desire and nation in Welsh literature. In H. Osbourne (Ed.), Queer Wales: the history, culture and politics of queer life in Wales (pp. 91-114). Cardiff: University of Wales Press.

Bohata, K. (2004). Postcolonialism revisited. Cardiff: University of Wales Press.

Chamberlain, B. (1962/1996). Tide-race. Bridgend: Seren.

Dafydd, F. (2016). Interview with Digital Literary Atlas of Wales project team.

Dafydd, F. (2008). Twenty thousand saints. Ceredigion: Alcemi.

Dafydd, F. (2006). Atyniad. Ceredigion: Y Lolfa.

Daniel, C. (1955). Bardsey: gate of Heaven. Liverpool: Catherine Daniel.

Davies, S. (2007) The Mabinogion. Oxford: Oxford University Press.

Evans, C. (1995). Island of dark horses. Bridgend: Seren. 
Evans, C., \& Marloh, W. (2008). Bardsey. Llandysul: Gomer.

Hay, P. (2006). A phenomenology of islands. Island Studies Journal, 1(1), 19-42.

Holm, B. (2000). Eccentric islands: travels real and imaginary. Minneapolis: Milkweed.

Hope Jones, P., \& Thomas, R.S. (1998). Between sea and sky: images of Bardsey. Llandysul: Gomer. Jarvis, M. (2008). Welsh environments in contemporary Welsh poetry. Cardiff: University of Wales Press.

Jones, R.W., \& Scully, R. (2012). Wales says yes: devolution and the 2011 Welsh referendum. Cardiff: University of Wales Press.

Norway, G., \& Smyth, G. (Eds.) (2002). Across the margins: cultural identity and change in the Atlantic archipelago. Manchester: Manchester University Press.

Polack, F. (1998). Writing and rewriting the island: Tasmania, politics and contemporary island fiction. In L. Brinklow, F. Ledwell, \& J. Ledwell (Eds.), Message in a bottle: the literature of small islands (pp. 215-230). Charlottetown: Institute of Island Studies, University of Prince Edward Island.

Reuschel, A.K., \& Hurni, L. (2011). Mapping literature: visualisation of spatial uncertainty in $\begin{array}{llll}\text { fiction. The } & \text { Cartographic }\end{array}$ https://doi.org/10.1179/1743277411Y.0000000023

Shell, M. (2015). Islandology: geography, rhetoric, politics. Stanford: Stanford University Press.

Thomas, M.W. (1992). Internal difference: literature in twentieth-century Wales. Cardiff: University of Wales Press.

Thomas, M.W., \& Aaron, J. (2003). "Pulling you through changes": Welsh writing in English before, between and after two referenda. In M.W. Thomas (Ed.), Welsh writing in English (pp. 278-309). Cardiff: University of Wales Press.

Walford Davies, D. (2012). Cartographies of culture: new geographies of Welsh writing in English. Cardiff: University of Wales Press. 
Kieron Smith et al. 